\title{
Developing a Theoretical Framework for Compliance Behavior of Income Zakat
}

Yusuf Haji-Othman, Mohd Sholeh Sheh Yusuff, Wan Nazjmi Mohamed Fisol

To Link this Article: http://dx.doi.org/10.6007/IJARBSS/v11-i9/11200

DOI:10.6007/IJARBSS/v11-i9/11200

Received: 12 July 2021, Revised: 18 August 2021, Accepted: 10 September 2021

Published Online: 27 September 2021

In-Text Citation: (Haji-Othman et al., 2021)

To Cite this Article: Haji-Othman, Y., Yusuff, M. S. S., \& Fisol, W. N. M. (2021). Developing a Theoretical Framework for Compliance Behavior of Income Zakat. International Journal of Academic Research in Business and Social Sciences, 11(9), 1579-1589.

\section{Copyright: (c) 2021 The Author(s)}

Published by Human Resource Management Academic Research Society (www.hrmars.com)

This article is published under the Creative Commons Attribution (CC BY 4.0) license. Anyone may reproduce, distribute, translate and create derivative works of this article (for both commercial and non-commercial purposes), subject to full attribution to the original publication and authors. The full terms of this license may be seen at: http://creativecommons.org/licences/by/4.0/legalcode

Vol. 11, No. 9, 2021, Pg. 1579 - 1589

Full Terms \& Conditions of access and use can be found at http://hrmars.com/index.php/pages/detail/publication-ethics 


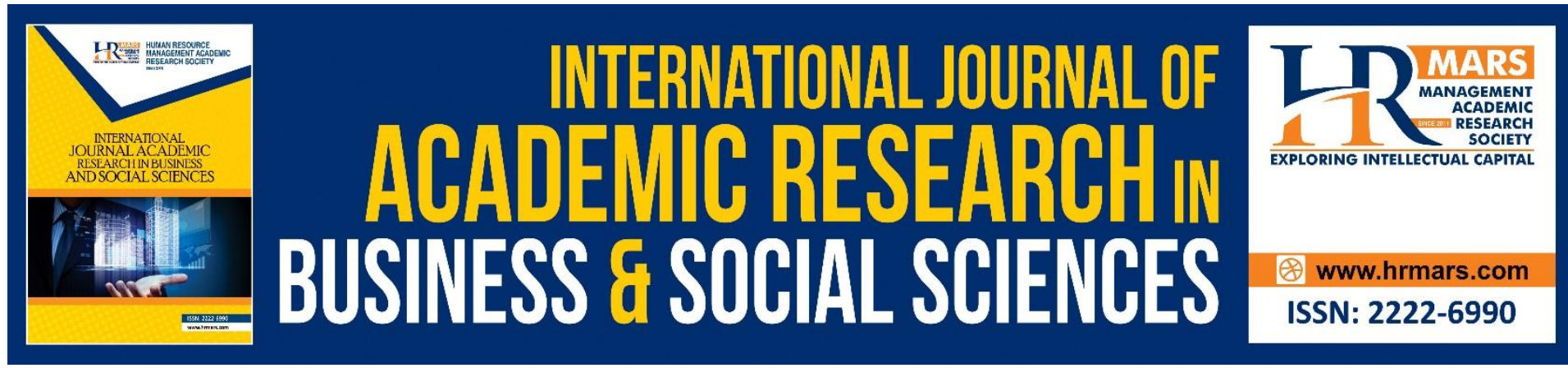

\title{
Developing a Theoretical Framework for Compliance Behavior of Income Zakat
}

\author{
Yusuf Haji-Othman, Mohd Sholeh Sheh Yusuff, Wan Nazjmi \\ Mohamed Fisol
}

Universiti Islam Antarabangsa Sultan Abdul Halim Mu'adzam Shah, Malaysia

\begin{abstract}
Despite a religious decree on the compulsory position of zakat on employment income in Malaysia, zakat collection indicates low compliance of income zakat. Studies on zakat compliance have shown mixed and inconclusive evidence regarding the determinants of income zakat compliance. Therefore, this study develops a theoretical framework to examine determinants of compliance behavior of income zakat. This study hopes to provide a comprehensive theoretical framework that could guide future studies on the compliance behavior of income zakat.
\end{abstract}

Keywords: Theoretical Framework, Compliance Behavior, Zakat.

\section{Introduction}

Studies on zakat compliance have shown mixed and inconclusive evidence regarding the determinants of income zakat compliance. Therefore, this study develops a theoretical framework to investigate determinants of compliance behavior of income zakat. This study, a conceptual paper, hopes to provide a comprehensive theoretical framework that could guide future studies on the compliance behavior of income zakat.

\section{Literature Review}

\section{Attitude and Compliance Behavior of Zakat}

There is voluminous literature that shows that attitude is a significant variable related to a particular behavior. Starting with Ajzen (1991), the study found some empirical evidence supporting the relationship between attitude towards behavior and intention to perform the behavior.

Sareye and Haji-Othman (2017) revealed that attitude and subjective norm have a positive and significant influence on intention towards paying zakat on business among single business owners at Kuala Ketil, Kedah. Also, attitude and perception towards law enforcement significantly influence the intention to comply with zakat on income (Farah et al., 2017). HajiOthman, Yusuff, et al (2017) revealed that attitude has significant relationships and a positive influence on intention. 
Haji-Othman, Alwi, et al (2017) also revealed that attitude significantly affects compliance behavior in pay income zakat among educators. Saad et al (2010) also found that attitude played an essential role in influencing business zakat compliance behavior. Saad et al (2008) found that the attitude and subjective norm played significant roles in influencing business zakat compliance.

\section{Subjective Norms and Compliance Behavior}

Ajzen (1991) defines subjective norm as "the perceived social pressure to perform or not to perform the behavior." The Theory of Planned Behavior (TPB) and Technology Acceptance Model (TAM) have examined subjective norms as independent and moderating variables. Khaled et al (2014) revealed that subjective norms significantly influenced Yemen's banking services.

Subjective norm has also been tested in the setting of intention to purchase products and services. Al-Swidi et al (2014) revealed that subjective norms significantly moderated the relationship between attitudes and buying intention and perceived behavior control and purchase intention. Furthermore, subjective norms significantly influenced attitude toward purchase intention. Budiman and Wijaya (2014) backed this finding when the study established a positive relationship between subjective norms and purchase intention.

Moreover, Heuer and Liñán (2013) further supported this finding when the study provided evidence that subjective norms played a significant role in entrepreneurial intention. In a survey on social networking sites (SNS), Choi and Chung (2013) demonstrated that subjective norm and perceived social capital were significant determinants of perceived usefulness and perceived ease of SNS use. On the contrary, Eckhardt (2009) discovered a significant negative correlation between the significant impact of subjective norms on intention to adopt information technology (IT). Renfroe, O'Sullivan, \& McGee (1988) refuted this finding when the study revealed that subjective norm had a significant positive effect on the behavioral intention of staff nurses to be responsible for documentation which is an integral part of patient care.

Previous studies have received mixed empirical evidence supporting subjective norm as a significant determinant of tax intention to compliance behavior. Among the studies which studied subjective norm as a predictor of tax compliance behavior includes (Hite, 1988; Trivedi, Shehata \& Lynn, 2003; Bobek and Hatfield, 2003; Bobek, Roberts \& Sweeney, 2007; Davis, Hecht \& Perkins, 2003; Faa, 2008; Palil and Mustapha, 2011).

Bobek and Hatfield (2003) discovered that subjective norm was a significant variable influencing tax compliance intention. Bobek et al (2007) examined the influence of social norms on tax compliance intention in Australia, Singapore, and the United States. The study revealed that social norm was a significant determinant of tax compliance intention, supporting this finding. Faa (2008), who observed the determinants of tax compliance behavior using descriptive analysis and multivariate analysis, reinforced this idea. The study verified that peer influence had significant relationships with tax compliance. Palil and Mustapha (2011) further maintained this finding when it revealed that subjective norms influenced tax compliance. Likewise, Natrah (2011) provided additional empirical evidence 
indicating that subjective norm was a significant determinant of tax compliance behavior by Malaysian and New Zealand taxpayers.

Chung and Trivedi (2003) revealed that friendly persuasion significantly influenced tax compliance, further reinforcing these findings. In the same way, Zainol and Faridahwati (2013) provided additional supporting empirical evidence when they probed the influence of attitude and subjective norms on the intention of taxpayers to comply with Goods and Service Tax (GST) in Malaysia. The study discovered that subjective norms significantly influenced the taxpayers' intention to comply with GST.

However, Trivedi, Shehata, and Lynn (2003) exposed mixed evidence of peers' significance on tax compliance. They tested the impact of personal and situational factors on taxpayer compliance using an experimental analysis. The study established that the presence of noncompliance peers negatively influenced compliance of tax behavior. However, the presence of compliant peers did not affect the compliance behavior of taxpayers. Trivedi, Shehata, and Lynn (2003) found that compliant peers' presence did not influence taxpayers' compliance behavior. Hite (1988) revealed that peer reporting of tax had no direct influence on tax compliance behavior.

In the environment of zakat compliance, Zainol et al (2009) inspected whether subjective norms and attitudes towards zakat were directly related to intention to comply with zakat on employment income in Malaysia and examined whether attitudes towards zakat mediate the relationship between subjective norms and intention. The study exposed that subjective norms and attitudes had a positive and significant influence on behavioral intention. Zulkifli \& Sanep (2010) found that subjective norms significantly influenced zakat compliance behavior and supported this evidence. Nonetheless, Bidin, Othman and Azman (2013) disputed this finding when they demonstrated that subjective norms had no significant influence on intention to comply with zakat on saving.

Zainol (2008) verified that a multidimensional subjective norm consisting of spouse, parents, and zakat amil was a significant factor in zakat compliance behavioral intention. Saad (2010a), who reinforced the influence of spouse, peers, parents, and zakat amil, supported the finding on intention and compliance behavior of income zakat. The studies so far have shown mixed results regarding the influence of subjective norms on intention and compliance behavior. Although Ajzen (1991) postulates that subjective norms influence intention to perform a particular behavior, the evidence is still inconclusive, triggering further reexamination.

\section{Perceived Behavioral Controls and Compliance Behavior}

Ajzen and Madden (1986) expanded the Theory of Reasoned Action (TRA) by adding perceived behavioral control into the model and verified that perceived behavioral control significantly correlated with intention and compliance behavior. Perceived behavioral control denotes people's perceptions of their ability to perform a particular behavior. Certain beliefs sway it about specific influences that encourage people to achieve a specific behavior or discourage people from committing the behavior (Ajzen, 1991b). Perceived behavioral control is "the extent to which people consider the performance of behavior to be under their voluntary control" (Trafimow, Sheeran, Conner, and Finlay, 2002). Perceived behavioral control 
encompasses separable components that reflect beliefs about self-efficacy and controllability (Ajzen, 2002). It consists of two parts: self-efficacy and controllability (Ajzen, 2002).

Perceived behavioral control is an explanatory variable in several theories, such as the Theory of Planned Behavior (TPB). It has been studied in various fields such as career planning, medicine, marketing, tax, and zakat. Hsu (2012) revealed that perceived behavioral control positively influenced intention and behavior to plan careers among college students. Similarly, France et al (2013) evidenced that perceived behavioral control had a significant relationship with the intent to donate blood.

A voluminous literature has studied tax and zakat's compliance behavior that has used perceived behavioral control as one of the constructs explaining the intention to perform the behavior. Bidin et al (2013) attested that perceived behavioral control significantly influenced intention to comply with zakat on saving.

\section{Moral Obligation and Compliance Behavior of Income Zakat}

Braithwaite et al (2006); Torgler (2004); Alm and Torgler (2006); Alm and Torgler (2011) and Halla, 2010) used moral obligation as an independent variable. On the other hand, Bobek and Hatfield (2003) used moral obligation as a moderating variable using TPB as the framework to study tax compliance behavior. The study revealed that when the moral obligation acts as a moderating variable in the Theory of Planned Behavior (TPB), it is a significant moderating variable to tax noncompliance. Haji-Othman (2016) revealed that moral obligation has a significant relationship and positive influences on intention. Haji-Othman et al (2019) also showed that moral obligation is a significant determinant of intent to comply with income zakat payment.

\section{Religiosity and Compliance Behavior of Zakat}

There have been limited studies that have examined the influence of religiosity on zakat compliance. Yusuff, et al (2018) proposed that religiosity, subjective norms, and perceived behavioral control influence compliance behavior.

Idris et al (2012) examined whether the Islamic religiosity measurement plays a significant role in the compliance behavior of zakat. The study used questionnaires as instruments with a sample size of 227 . The study concluded that the measurement of the component of religiosity has four dimensions. This study found that highly religious business owners are also more likely to comply with zakat law and that religiosity plays a significant role in zakat compliance behavior.

Yusuff, et al (2017) provided evidence that Islamic religiosity significantly influences compliance behavior to pay employment income zakat. Haji-Othman, Alwi, et al (2017) revealed that three variables explain the compliance behavior of income zakat: religiosity, subjective norms, and perceived behavioral control.

Islamic religiosity, however, did not show any significant influence on zakat compliance (Farah et al., 2017). However, Zainol (2008) found that religiosity was an important factor that relates positively to zakat compliance behavioral intention. 


\section{Theoretical Framework of the Study}

The theoretical framework is adapted and adopted from Ajzen (1991) and based on deductive reasoning. There are four independent variables: attitude, religiosity, self-efficacy, and moral obligation, while compliance is the dependent variable.

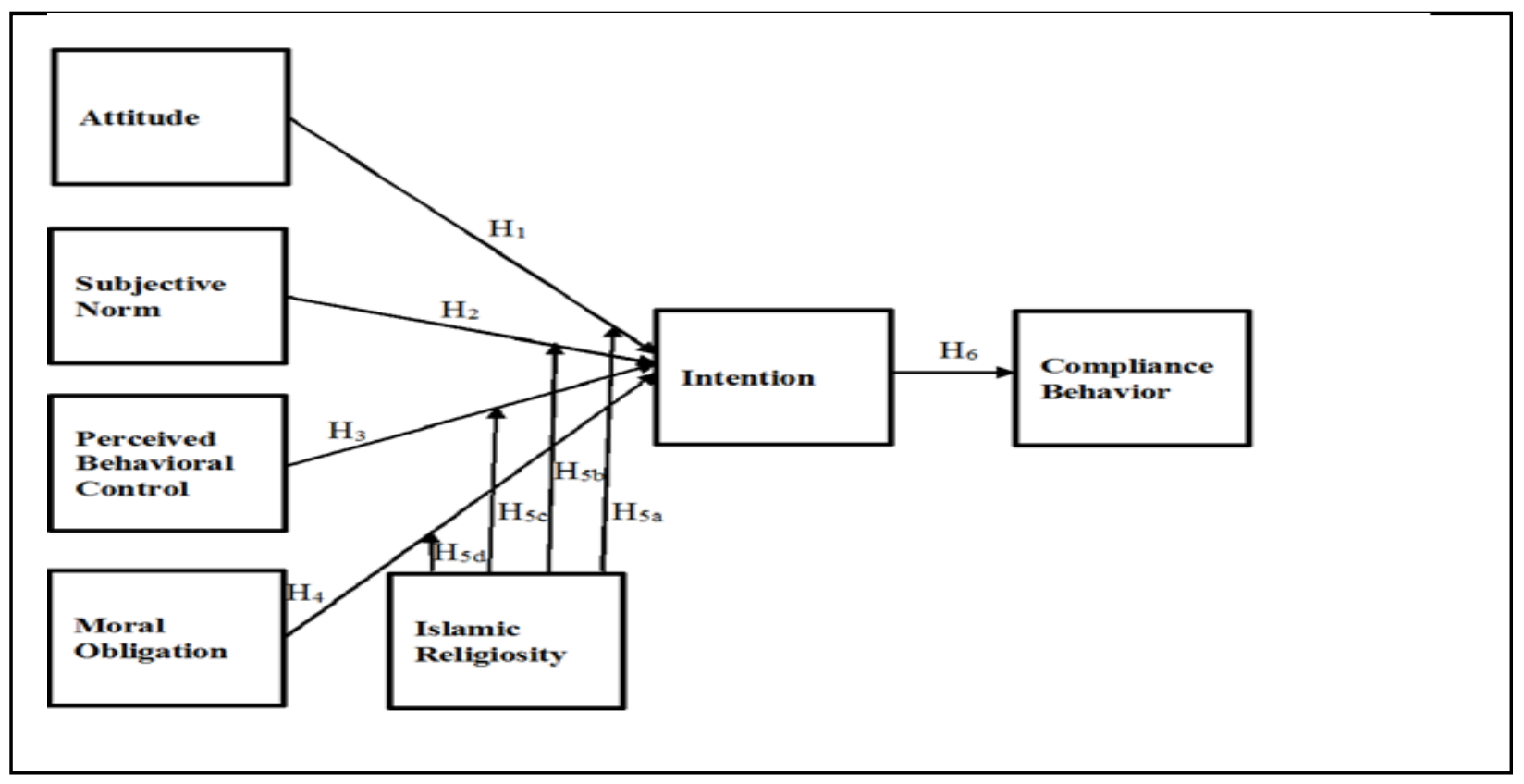

Figure 1. Theoretical Framework of the Study

This study adopts the theoretical framework from Ajzen (1991) and bases on deductive reasoning. This study uses deductive reasoning to expand the theoretical framework and add new variables to the theoretical framework suggested by Karjaluoto, Matilla, \& Pento (2002). In this study, endogenous variables are the intention to pay income zakat and the compliance behavior of income zakat. According to Ajzen (1991b); Armitage and Conner (2001); Conner and Armitage (1998); Ajzen (2006), intention influences compliance behavior, and intention, on the other hand, is influenced by attitude, subjective norm and perceived behavioral control. For this study, moral obligation is the fourth independent variable. In addition, religiosity is the moderating variable.

Based on the theoretical framework, attitude is the first construct that determines the intention to pay zakat. This study selects attitude following (Hite, 1988; Niemirowski et al., 2003; Ghosh and Crain, 1995; Kasipillai and Hijattulah, 2006; Marti, Wanjohi and Magutu, 2010; Bidin et al., 2009; Bidin et al., 2009; Loo, Mckerchar \& Hansford, 2010; Randlane, 2012; Trivedi, Shehata \& Mestelman, 2005).

The construct of attitude needs to be decomposed into several dimensions to understand the attitude construct. This study constructs five dimensions of attitude: agreeing, supporting, rejecting, conditional and skeptical dimensions following Ram Al Jaffri (2010). This study hypothesizes that attitude towards income zakat compliance behavior has a direct positive relationship with intention to pay income zakat. 
The second construct of TPB is subjective norms. Based on previous studies such as Hite (1988); Trivedi et al (2003); Bobek and Hatfield (2003); Bobek, Roberts and Sweeney (2007); Davis, Hecht, and Perkins (2003); Faa (2008); Rizal (2010), this study hypothesizes that subjective norms have a positive influence on intention. Five referent groups are expected to influence the intention to pay zakat: spouses, parents, peers, religious teachers, and zakat amil.

The third construct is perceived behavioral control, which consists of two categories: internal and external control. Knowledge and self-efficacy are dimensions of internal perceived behavioral control. At the same time, perception towards promotional exposure, perception towards law and enforcement, perception towards service quality, perception towards the facility, perception towards the fairness of distribution, and tax rebate are dimensions of external perceived behavioral control.

Unlike Ajzen (1991) TPB framework, which consists of the three constructs: attitude, subjective norms, and perceived behavioral control, the theoretical framework of this study consist of five constructs. Besides the three constructs, the framework of this study added fourth and fifth constructs: moral obligation and religiosity.

Moral obligation is incorporated in this study because it reflects intrinsic motivation to perform a particular behavior. Therefore, it is expected to influence the intention to comply with specific behavior. Braithwaite et al (2006); Torgler (2004a); Alm and Torgler (2006); Alm and Torgler (2011); Halla (2012) supported this relationship.

Furthermore, this study chooses Islamic religiosity as a moderating variable in the theoretical framework of the study. This study hypothesizes that Islamic religiosity, which the Muslim Religiosity-Personality Measurement Inventory measures (MRPI), moderates the relationship between attitude, subjective norm, perceived behavioral control and moral obligation, and intention to pay income zakat. For the study, MRPI is adopted from (Krauss et al., 2005).

This study considers the inclusion of religiosity because of the role it plays in influencing behavior. So far, voluminous studies have examined the impact of religiosity in many areas, including tax and zakat compliance. Such studies include Idris (2002); Torgler (2003); Bidin (2008); Idris, Bidin \& Saad (2012b), Abu Bakar and Abdul Rashid (2010); Palil, Rusyidi, and Ahmad (2013); Saad (2010b); Rahim et al (2011); Saad (2010a); Saad et al (2010), Idris et al (2012b); Mohdali and Pope (2014). However, this study differs from the previous studies in that it employs religiosity measurement from an Islamic perspective. The use of Islamic religiosity is important since zakat payment is a religious obligation. Religiosity is crucial because it guides Muslims in discharging their duties, including compliance behavior to religious obligations such as salat, zakat, and hajj.

\section{Conclusion}

Zakat is an essential Islamic social finance instrument that could finance specific programs to achieve social, political, and economic development among Muslim communities. However, the issue which arises is that zakat collection, including income zakat, is still low, which hinders the effectiveness of zakat in playing a more significant role in the state of Kedah. This study develops a theoretical framework of compliance behavior of income zakat that future studies could use. This study recommends that future studies on zakat compliance adapt and 
adopt this theoretical framework to obtain more in-depth information about determinants of zakat compliance. This study suggests that future studies explore the compliance behavior of zakat in countries where the governments have not established zakat institutions under the law. Nonetheless, this study hopes to guide future studies to conduct further research to extend the boundary of knowledge pertaining to the compliance of income zakat.

\section{References}

Abu Bakar, N. B., \& Abdul Rashid, H. M. (2010). Motivations of Paying Zakat on Income: Evidence from Malaysia. International Journal of Economics and Finance, 2(3), 76-84.

Ajzen, I. (2002). Perceived Behavioral Control, Self-efficacy, Locus of Control, and the Theory of Planned Behavior. J. Appl. Soc. Psychol., 32(4), 665-683. https://doi.org/10.1111/j.1559-1816.2002.tb00236.x

Ajzen, I, \& Madden, T. (1986). Prediction of Goal-Directed Behavior: Attitudes, Intentions, and Perceived Behavioral Control. Journal of Experimental Social Psychology, 22(5), 453-474. https://doi.org/10.1016/0022-1031(86)90045-4

Ajzen, I. (1991). The Theory of Planned Behavior. Orgnizational Behavior and Human Decision Processes, 50, 179-211. https://doi.org/10.1016/0749-5978(91)90020-T

Ajzen, I. (2006). Behavioral Interventions Based on the Theory of Planned Behavior.

Al-Swidi, A., Huque, R. S. M., Hafeez, M. H., \& Shariff, M. N. (2014). The Role of Subjective Norms in Theory of Planned Behavior in the Context of Organic Food Consumption. British Food Journal, 116(10), 1561-1580. https://doi.org/10.1108/BFJ-05-2013-0105

Alm, J., \& Torgler, B. (2006). Culture Differences and Tax Morale in the United States and in Europe. Journal of Economic Psychology, 27, 224-246. https://doi.org/10.1016/j.joep.2005.09.002

Alm, J., \& Torgler, B. (2011). Do Ethics Matter? Tax Compliance and Morality. Journal of Business Ethics, 101(4), 635-651. https://doi.org/10.1007/s10551-011-0761-9

Armitage, C. J., \& Conner, M. (2001). Efficacy of the Theory of Planned Behaviour: a Metaanalytic Review. The British Journal of Social Psychology/the British Psychological Society, 40(Pt 4), 471-499. http://www.ncbi.nlm.nih.gov/pubmed/11795063

Bidin, Z. (2008). Faktor-faktor Penentu Niat Gelagat Kepatuhan Zakat Pendapatan Gaji.

Bidin, Z., Idris, M. K., \& Shamsudin, M. F. (2009). Predicting Compliance Intention on Zakah on Employment Income in Malaysia: An Application of Reasoned Action Theory. Jurnal Pengurusan, 28, 85-102.

Bidin, Z., Othman, M. Z., \& Azman, N. F. M. (2013). Zakat Compliance Intention Behavior on Saving among Universiti Utara Malaysia's Staff. Proceeding of the International Conference on Social Science Research, Penang Malaysia, June 2013, 145-155. https://doi.org/OYA Graduate School of Business

Bobek, D. D., \& Hatfield, R. C. (2003). An Investigation of the Theory of Planned Behavior and the Role of Moral Obligation in Tax Compliance. Behavioral Research in Accounting, 15, 13-38.

Bobek, D. D., Roberts, R. W., \& Sweeney, J. T. (2007). The Social Norms of Tax Compliance: Evidence from Australia, Singapore, and the United States. Journal of Business Ethics, 74(1), 49-64. https://doi.org/10.1007/s10551-006-9219-x

Braithwaite, V., Reinhart, M., \& Smart, M. (2006). Tax Non-Compliance among the Under-30s (Issue c, pp. 256-280).

Budiman, S., \& Wijaya, T. (2014). Purchase Intention of Counterfeit Products: The Role of Subjective Norm. International Journal of Marketing Studies, 6(2), 145-152. 
https://doi.org/10.5539/ijms.v6n2p145

Choi, G., \& Chung, H. (2013). Applying the Technology Acceptance Model to Social Networking Sites (SNS): Impact of Subjective Norm and Social Capital on the Acceptance of SNS. International Journal of Human-Computer Interaction, 29(10), 619-628. https://doi.org/10.1080/10447318.2012.756333

Chung, J., \& Trivedi, V. U. (2003). The Effect of Friendly Persuasion and Gender on Tax Compliance Behavior. Journal of Business Ethics, 47, 133-145.

Conner, M., \& Armitage, C. J. (1998). Extending the Theory of Planned Behavior: A Review and Avenues for Further Research. Journal of Applied Social Psychology, 28(15), 1429-1464. https://doi.org/10.1111/j.1559-1816.1998.tb01685.x

Davis, J. S., Hecht, G., \& Perkins, J. D. (2003). Social Behaviors, Enforcement, and Tax Compliance Dynamics. The Accounting Review, 78(1), 39-69. https://doi.org/10.2308/accr.2003.78.1.39

Eckhardt, A. (2009). The Significant Others of Subjective Norm - A Scientometric Study of Subjective Norm in IS Top-Journals over Two Decades. Proceedings of the 17th European Conference on Information Systems (ECIS 2009), 1-12. papers3://publication/uuid/8dd99c21-2555-44a6-b12b-cbd50fb3404c

Faa, S. G. (2008). Tax Compliance Behavior of Individuals Under Self Assessment System.

France, J. L., Kowalsky, J. M., France, C. R., Mcglone, S. T., Himawan, L. K., Kessler, D. A., \& Shaz, B. H. (2013). Development of Common Metrics for Donation Attitude, Subjective Norm, Perceived Behavioral Control, and Intention for the Blood Donation Context. Transfusion. https://doi.org/10.1111/trf.12471

Ghosh, D., \& Crain, T. L. (1995). Ethical Standards, Attitudes Toward Risk, and Intentional Noncompliance: An experimental Investigation. Journal of Business Ethics, 14(5), 353365. https://doi.org/10.1007/BF00872098

Halla, M. (2010). First Evidence on a Causal Link Tax Morale and Compliance Behavior: First Evidence on a Causal Link (Issue 4918).

Halla, M. (2012). Tax Morale and Compliance Behavior: First Evidence on a Causal Link. B.E. Journal of Economic Analysis and Policy, 12(1). https://doi.org/10.1515/1935-1682.3165

Heuer, A., \& Liñán, F. (2013). Testing Alternative Measures of Subjective Norms in Entrepreneurial Intention Models. International Journal of Entrepreneurship and ..., 19(1), 35-50. https://doi.org/10.1504/IJESB.2013.054310

Hite, P. A. (1988). The Effect of Peer Reporting Behavior on Taxpayer Compliance. The Journal of the American Taxation Association, 47-64.

Hsu, M. S. (2012). A study of Internship Attitude, Subjective Norm, Perceived Behavioral Control, and Career Planning of Hospitality Vocational College Students. Journal of Hospitality, Leisure, Sport and Tourism Education, 11(1), 5-11. https://doi.org/10.1016/j.jhlste.2012.02.003

Karjaluoto, H., Matilla, M., \& Pento, T. (2002). Electronic Banking in Finland: Consumer Beliefs and Reactions to a New Discovery Channel. Journal of Financial Services Marketing, 6(4), 346-361.

Kasipillai, J., \& Abdul Jabbar, H. (2006). Gender and Ethnicity Differences in Tax Compliance. Asian Academy of Management Journal, 11(2), 73-88.

Khaled, M. A., Isa, M. F., Othman, S. N., \& Hussein, A. S. Z. (2014). The Impact of Students' Attitude and Subjective Norm on the Behavioural Intention to Use Services of Banking System. International Journal of Business Information Systems, 15(1), 105. https://doi.org/10.1504/IJBIS.2014.057967 
Krauss, S. E., Hamzah, H. A., Suandi, T., Noah, M. S., Mastor, K. A., Juhari, R., Kassan, H., Mahmoud, A., \& Jamiah, M. (2005). The Muslim Religiosity-Personality Measurement Inventory ( MRPI )'s Religiosity Measurement Model: Towards Filling the Gaps in Religiosity Research on Muslims. Pertanika J. Soc. Sci. \& Hum., 13(2), 131-145.

Loo, E. C., Mckerchar, M., \& Hansford, A. (2010). Findings on the Impact of Self Assessment on the Compliance Behaviour of Individual Taxpayers in Malaysia: A Case Study Approach.

Marti, L. O., Wanjohi, M. S., \& Magutu, O. (2010). Taxpayers ' Attitude and Tax Compliance Behaviour in Kenya: How the Taxpayers' Attitudes Influence Compliance Behavior among SMEs Business Income Earners in Kerugoya Town, Kirinyaga District. African Journal of Business Management, 1, 112-122.

Idris, M. K. (2002). Gelagat Kepatuhan Zakat Pendapatan Gaji di Kalangan Kakitangan Awam Persekutuan Negeri Kedah. Universiti Utara Malaysia.

Idris, M. K., Bidin, Z., \& Saad, R. A. J. (2012). Islamic Religiosity Measurement and its Relationship with Business Income Zakat Compliance Behavior. Jurnal Pengurusan, 34, 3-10.

Rahim, M. K., Ariffin, M. S., \& Abd Samad, N. (2011). Compliance Behavior of Business Zakat Payment in Malaysia: A Theoretical Economic Exposition. 8th International Conference on Islamic Economics and Finance, 1-17.

Mohdali, R., \& Pope, J. (2014). The Influence of Religiosity on Taxpayers' Compliance Attitudes. Accounting Research Journal, 27(1), 71-91. https://doi.org/10.1108/ARJ-082013-0061

Natrah, S. (2011). Fairnes, Perceptions and Compliance Behavior: Taxpayers' Judgements in Self-assessment Environments.

Niemirowski, P., Baldwin, S., \& Wearing, A. J. (2003). Tax Related Behaviours, Beliefs, Attitudes and Values and Taxpayer Compliance in Australia. Journal of Australian Taxation, 6(1), 132-165.

Palil, M. R., Rusyidi, M. A., \& Ahmad, W. F. (2013). The Perception of Tax Payers on Tax Knowledge and Tax Education with Level of Tax Compliance: A Study the Influences of Religiosity. ASEAN Journal of Economics, Management and Accounting, 1(1), 118-129.

Palil, M. R., \& Mustapha, A. F. (2011). Factors Affecting Tax Compliance Behaviour in SelfAssessment System. African Journal of Business Management, 5(33). https://doi.org/10.5897/AJBM11.1742

Randlane, K. (2012). Tax Compliance and Tax Attitudes: The Case of Estonia. Journal of Management and Change, 29.

Renfroe, D., O'Sullivan, P., \& McGee, G. (1988). The Relationship of Attitude, Subjective Norm, and Behavioral Intention to the Documentation Behavior of Nurses. In Relationship of Attitude, Subjective Norm \& Behavioral Intention to the Documentation Behavior of Nurses.

http://search.ebscohost.com/login.aspx?direct=true \&db=ccm\&AN=109868372\&site=e host-live\&scope=site

Saad, R. A. J. (2010a). Gelagat Kepatuhan Zakat Perniagaan di Negeri Kedah Darul Aman.

Saad, R. A. J. (2010b). Gelagat Kepatuhan Zakat Perniagaan: Apakah Penentunya? 4th ISDEV International Islamic Development Management Conference (IDMAC 2010), 1-17.

Saad, R. A. J., Bidin, Z., Idris, M. K., \& Hussain, M. H. (2010). Faktor-Faktor yang Mempengaruhi Gelagat Kepatuhan Zakat Perniagaan. Jurnal Pengurusan, 30, 49-61.

Torgler, B. (2004). Cross-Culture Comparison of Tax Morale and Tax Compliance: Evidence from Costa Rica and Switzerland. International Journal of Comparative Sociology, 45(1- 
2), 17-43. https://doi.org/10.1177/0020715204048309

Trafimow, D., Sheeran, P., Conner, M., \& Finlay, K. a. (2002). Evidence that Perceived Behavioural Control is a Multidimensional Construct: Perceived Control and Perceived Difficulty. The British Journal of Social Psychology / the British Psychological Society, 41(Pt 1), 101-121. https://doi.org/10.1348/014466602165081

Trivedi, V. U., Shehata, M., \& Lynn, B. (2003). Impact of Personal and Situational Factors on Taxpayer Compliance : An Experimental Analysis. Journal of Business Ethics, 47, 175-197. Trivedi, V. U., Shehata, M., \& Mestelman, S. (2005). Attitudes, Incentives and Tax Compliance (Issue August 2004).

Zainol, B., \& Faridahwati, M. S. (2013). Using Theory of Reasoned Action to Explain Taxpayer Intention to Comply with Goods and Services Tax ( GST ). Middle-East Journal of Scientific Research, 17(3), 387-394. https://doi.org/10.5829/idosi.mejsr.2013.17.03.12167

Zulkifli, D., \& Sanep, A. (2010). Kesan Perundangan Zakat ke atas Kepatuhan Bayaran Zakat: Ke arah Strategi Berkesan Program Pengurusan Kutipan Zakat. The 4th ISDEV International Islamic Development Management Conference (IDMAC 2010), December, 1-17. 